\title{
ONE TIME PASSWORDLESS and IP ADDRESS AUTHENTICATION METHOD
}

\author{
for WEB APPLICATION
}

\author{
Mohammad Sani Suprayogi \\ Program Studi Teknik Informatika \\ Universitas Semarang \\ Semarang, Indonesia \\ yogie@usm.ac.id
}

\begin{abstract}
Penelitian yang membahas model autentikasi pengguna, mulai dari autentikasi tradisional menggunakan username dan password hingga metode multi-factorauthenticationtelah sering dilakukan. Namun model autentikasi tersebut masih menggunakan password, dimana manusia memiki keterbatasan untuk mengingat sehingga resiko kehilangan password kerap terjadi. Selain itu pencurian data pada jaringan komputer masih marak dilakukan sehingga perlu pendekatan lain dalam autentikasi pengguna terhadap sistem.

Passwordlessauthentication adalah model autentikasi yang mulai dikenalkan, hanya saja proses implementasinya masih terbatas. Paper ini berusaha meningkatkan metode passwordless dengan tambahan time limit, session, dan ipaddress dalam melakukan autentikasi pengguna.

Hasilnya, pengguna tidak perlu membuat dan mengingat password. Pengguna cukup memanfaatkan layanan email untuk proses registrasi dan login, kemudian ipaddress menjamin bahwa hanya pengguna tersebut yang dapat mengakses layanan website.
\end{abstract}

Keywords - passwordless; authentication; security;

\section{Pendahuluan}

Pada aplikasi web, faktor keamanan akan selalu menjadi isu utama.Aplikasi yang dibangun dengan bahasa PHP perlu memperhatikan lima ancaman dari peretas, yaitu: remote code execution, cross-site scripting (XSS), SQL injection (SQLI), dan PHP configuration and file system attacks. Selain itu,autentikasi pengguna juga perlu

${ }^{1}$ https://www.owasp.org/index.php/PHP_Top_5 diperhatikan supaya menjamin kenyamanan dan keamanan pengguna.

Penelitian berbagai model autentikasi pengguna pada aplikasi web telah sering dilakukan, namun pada sisi implementasi masih menggunakan model tradisional dengan pemanfaatan username dan password sebagai basis autentikasi user. Padahal Xiaoling and Jidong [1] menyebutkan bahwa penggunaan username dan password memiliki kelemahan, proses autentikasi yang menggunakan data yang tersimpan di server yang sama akan meningkatkan resiko keamanan meskipun telah menerapkan algoritma enkripsi seperti MD5.

Penelitian yang membahas passwordless sebelumnya telah dilakukan. Shirali-Shahreza and Shirali-Shahreza [2] telah menggunakan CAPTCHA $^{2}$ tetapi baru dikhususkan pada aplikasi mobile. Pembahasan untuk aplikasi web telah dilakukan namun masih mengandalkan cookies web browser sebagai pelindung[3]dimanacookies dapat diretas, selain itu ancaman penyadapan pada jaringan juga masih terbuka [4-6]. Sebelumnya Sælensminde and Boonjing [7] mengusulkan metode passwordless yang sederhana, maka kali ini penulis mempertimbangkan pemanfaatan time limit, session, dan ipaddress untuk meningkatkan penelitian tersebut.

Paper ini terstruktur sebagai berikut: Bagian II membahas sistem sekarang. Bagian III mengenai sistem yang diusulkan dan bagian IV merupakan contoh implementasi dan dibahas pada bab V. Kami memberikan kesimpulan pada bagian VI.

${ }^{2}$ Completely Automated Public Turing test to tell Computers and Human Apart 


\section{Sistem SeKarang}

Proses registrasi dan login pada aplikasi web secara umum masih menerapkan metode username dan password sebagai autentikasi pengguna walaupun beberapa layanan telah meningkatkan pengamanannya dengan metode multi-factorauthentication. Internet Banking di Indonesia telah mewajibkan penggunaan perangkat token untuk mengakses fitur perbankan, Outlook dan WordPress memanfaatkan aplikasi OTP generator, kemudian Facebook dan Gmail telah menerapkan two-factorauthentication memanfaatkan teknologi SMS.

Penelitian mengenai peningkatan dari sistem autentikasi tradisional menjadi multifactorauthentication juga telah dilakukan [812], namun pengguna tetap diharuskan untuk menginputusername dan password untuk dapat menggunakan layanan. Selain itu pemanfaatan teknologi SMS memiliki kelemahan apabila pengguna tidak berada pada wilayah yang tercover sinyal telepon. Miller [13] mengatakan bahwa twostepverification hanya cocok untuk geek, sedangkan bagi pengguna biasa proses autentikasi ini dirasa menyeramkan.

Graham [14]telah mengimplementasikan layanan tanpa password pada aplikasi Shop ItToMe $^{3}$, dimana pengguna cukup menggunakan akun email untuk mendaftar dan mengakses layanannya. Pada aplikasi tersebut, pengguna hanya mengisi alamat email pada form yang disediakan, kemudian sistem akan mengirimkan balasan email yang berisi alamat url unik yang hanya dapat diakses sekali waktu.

Metodeautentikasi yang penulisusulkan mengadopsi sistem autentikasi Shop ItToMe namun penggunaannya diperuntukkan ke aplikasi web dengan pengamanan yang lebih diperketat.

\section{Sistem YANG DiUSUlKaN}

Pada metode yang diusulkan, setiap pengguna akan melakukan beberapa hal berikut untuk mengakses web:

\section{Pengguna klik menu login.}

${ }^{3}$ https://itunes.apple.com/us/app/shop-it-to-me-designerclothes/id739426106
2. Pengguna memasukkan alamat email sebagai username.

3. Sistem memeriksa alamat email apakah telah terdaftar.

\section{A. Email Belum Terdaftar}

Apabila email belum terdaftar, maka sistem akan melakukan proses registrasi dengan langkah sebagai berikut:

1. Sistem mencatat ipaddress pengguna dan waktu akses kemudian mengirimkan email yang berisi alamat urlaktivasi beserta informasi time limit.

2. Pengguna melakukan klik pada alamat url.

3. Sistem mengecek apabila pengguna telah melewati time limit maka pengguna diwajibkan mengulang proses registrasi.

4. Sistem melakukan autentikasi berdasarkan alamat url yang diakses beserta ipaddress yang tercatat.

5. Bila autentikasi berhasil, sistem akan membuatkan session bagi pengguna.

6. Pengguna telah terdaftar dan mendapatkan akses ke dalam website.

\section{B. Email Telah Terdaftar}

Apabila email telah terdaftar, maka sistem akan melakukan prosedur login dengan langkah sebagai berikut:

1. Sistem mencatat ipaddress pengguna dan waktu akses kemudian mengirimkan email berisi alamat $u r l$ yang digunakan untuk mengakses dashboard beserta informasi time limit.

2. Pengguna melakukan klik pada alamat url.

3. Sistem mengecek apabila pengguna telah melewati time limit maka pengguna diwajibkan mengulang prosedur login.

4. Sistem melakukan autentikasi berdasarkan alamat url yang diakses beserta ipaddress yang tercatat.

5. Bila autentikasi berhasil, sistem akan membuatkan session bagi pengguna.

6. Pengguna mendapatkan akses ke dalam website. 
Pada metode yang diusulkan ini, pengguna tidak perlu membuat atau mengingat password untuk mengakses web. Pengguna hanya memasukkan alamat email sebagai username kemudian membuka inbox email untuk mengakses webmelalui alamat url unik yang dikirimkan oleh sistem. Kerahasiaan data diserahkan kepada penyedia layanan email yang telah memiliki sistem pengamanan data sendiri ditambah perlindungan dari $\mathrm{SSL}^{4}$.

Selain itu pengguna juga diharuskan menggunakan perangkat yang sama untuk mengakses web karena sistem autentikasi bekerja berdasarkan ipaddress yang digunakan saat proses login, sehingga dapat mengurangi ancaman penyadapan alamat $\mathrm{url}$.

\section{IMPLEMENTASI}

Implementasi yang kami lakukan tidak mencakup keseluruhan sistem, namun membahas pada bagian utama autentikasi yang meliputi:

1. Pengecekan alamat email.

2. Pengiriman alamat url.

3. Autentikasi pengguna

4. Login ke website

\section{A. Pengecekan Alamat Email}

Fungsi utama pada tahap ini melakukan pengecekan terhadap alamat email apakah pengunjung telah terdaftar sebagai pengguna yang kemudian akan menentukan prosedur selanjutnya.

get email address

if email address is not registered

if email address format is valid

do registration

end if

else

do login

end if

\section{B. Pengiriman Alamat URL}

Proses registrasi dan login memiliki fitur yang serupa yaitu mengirimkan email yang berisi alamat url sebagai jalan untuk mengakses website. Setiap url akan bersifat unik dan hanya dapat digunakan sekali waktu. get ip address get email address

get access time

set access time to H:i:s format

function token (access time, ip address) \{ create encryption from access time and ip address

\}

function url (email address, token) \{

get domain name

create url from domain name and token \}

function limit (access time) \{

addaccess time to 10 minutes \}

put ip address to database

put time access to database

put limit to database

put token to database

put url to database

put email address to database

send url to email address

\section{Autentikasi Pengguna}

Tahap autentikasi dilakukan setelah pengguna melakukan klik pada tautan url yang dikirimkan ke email. Sistem akan memeriksa ipaddress dan waktu akses pengguna dalam melakukan validasi.

get url

get ip address

getaccess time

function timing (access time) \{ get limit

ifaccess time $<$ limit

else timing is true

end if timing is false

\}

if timing is true

if ip address is same with database

if url is same with database

get email address

if email address is registered

else do login

register email address do login

end

end if end if

${ }^{4}$ Security Socket Layer 


\section{Login ke Website}

Tahap ini adalah saat pengguna berhasil diautentikasi oleh sistem, selanjutnya sistem akan mengikat pengguna dengan PHP session supaya dapat menjelajahi halaman web.

if ip address is same with database

if session is not registered register session

else access granted end if access granted end if

\section{Pembahasan Sistem}

Berdasarkan implementasi sederhana yang kami lakukan, pengguna tidak perlu membuat password untuk registrasi dan mengakses web. Sistem secara otomatis akan melakukan validasi alamat email, baik secara format penulisan ataupun status keanggotaan pada web. Selanjutnya, sistem akan mengirimkan email yang berisi alamat url unik yang terbuat dari kombinasi ipaddress dan waktu akses, sehingga alamat unik tersebut hanya dapat diakses oleh ipaddress tertentu dan dibatasi waktunya selama 10 menit setelah url terkirim.

Sistem autentikasi yang kami kerjakan dapat mengurangi resiko penyadapan yang dilakukan oleh peretas. Hal ini disebabkan alamat $u r l$ yang bersifat unik hanya dapat diakses oleh ipaddress yang terdaftar, selain itu alamat url hanya dapat diakses dalam jangka waktu 10 menit setelah terkirim ke alamat email pengguna. Session yang tercipta saat pengguna berhasil login ke web juga telah terlindungi berdasarkan ipaddress.

\section{KeSimpulan dan SARAN}

Berdasarkan hasil penelitian yang telah didapatkan, maka kami dapat menarik kesimpulan yaitu:

1. Metode passwordless dapat digunakan pada aplikasi web untuk mengurangi ketergantungan pengguna terhadap password.

2. Pengamanan berdasarkan pembatasan waktu akses, session, dan ipaddress dapat mengurangi resiko penyadapan oleh peretas.

Sebagai saran untuk penelitian selanjutnya, kami menyarankan hal-hal berikut:

1. Perlu penelitian lebih lanjut mengenai algoritma enkripsi yang digunakan saat pembuatan token.

2. Pengamanan lalu lintas data antara pengguna dengan server perlu diteliti lebih lanjut.

\section{REFERENCES}

[1] Z. Xiaoling and J. Jidong.,"Research for the application and safety of MD5 algorithm in password authentication in Fuzzy Systems and Knowledge Discovery (FSKD)",9th International Conference on 2012, pp. 2216-2219.

[2] M. Shirali-Shahreza and S. ShiraliShahreza, "Passwordless login system for mobile phones using CAPTCHA", in ELMAR 2007, pp. 243-246.

[3] F. Heinemann and R. Nyman., "Passwordless authentication: Secure, simple, and fast to deploy" Available:

https://hacks.mozilla.org/2014/10/pas swordless-authentication-securesimple-and-fast-to-deploy/

[4] S. Ansari, S. G. Rajeev, and H. S. Chandrashekar, "Packet sniffing: a brief introduction", Potentials 2002, IEEE, vol. 21, pp. 17-19.

[5] T. Chomsiri, "Sniffing Packets on LAN without ARP Spoofing. in Convergence and Hybrid Information Technology", ICCIT 2008, Third International Conference on 2008, pp. 472-477.

[6] S. Gupta and L. Sharma, "Exploitation of Cross-Site Scripting (XSS) Vulnerability on Real World Web Applications and its Defense", International Journal of Computer Applications, vol. 60, pp. 28-33.

[7] K. Sælensminde and V. Boonjing, "Simple password less authentication system for web sites", in Information 
Technology: New Generations (ITNG), 2010 Seventh International Conference on, 2010, pp. 132-137.

[8] S. K. Joram, G. Pelechaty, P. K. Chauhan, and S. Vittal, "Multiple factor user authentication system," US 2009/0063850 A1, Mar. 5, 2009.

[9] Y. Onda, S. SeongHan, K. Kobara, and H. Imai, "How to distinguish online dictionary attacks and password mis-typing in two-factor authentication," in Information Theory and its Applications (ISITA), 2010 International Symposium on, 2010, pp. 571-576.

[10] J. Steinberg, "System and method of using two or more multi-factor authentication mechanisms to authenticate online parties," US 2007/0136573 A1, Jun. 14, 2007.

[11] M. Ziqing, D. Florencio, and C. Herley, "Painless migration from passwords to two factor authentication," in Information Forensics and Security (WIFS), 2011 IEEE International Workshop on, 2011, pp. 1-6.

[12] Dr.P.Pandarinath and V. Yalamanchili, "Improved Password Authentication System against Password attacks for web Applications", International Journal of Computer Trends and Technology (IJCTT), vol. 4, pp. 2878-2883, 2013.

[13] R. Miller, "Why two-step verification will never work", Available: http://www.citeworld.com/article/211 5319/mobile-byod/two-stepverification-sucks.html.

[14] C. Graham, "Bye Bye, Password", Available:

http://blog.shopittome.com/2014/05/2 9/bye-bye-passwords/ 